\title{
HUBUNGAN PENINGKATAN NILAI KADAR CREATINE KINASE - MB MORTALITAS PASIEN SINDROMA KORONER AKUT (SKA)
}

\author{
Abraham Ahmad Ali Firdaus \\ (Universitas Nahdlatul Ulama Surabaya, Fakultas Kedokteran, Program Studi S1 \\ Pendidikan Dokter, Email: abraham.ahmad@unusa.ac.id) \\ Ardyarini Dyah Savitri \\ (Universitas Nahdlatul Ulama Surabaya, Fakultas Kedokteran, Program Studi S1 \\ Pendidikan Dokter, Email: vitri.sppd@unusa.ac.id) \\ Difran Nobel Bistara \\ (Universitas Nahdlatul Ulama Surabaya, Fakultas Keperawatan dan Kebidanan, \\ Program Studi D3 Keperawatan, Email: nobel@unusa.ac.id)
}

\begin{abstract}
ABSTRAK
Sindroma Koroner Akut (SKA) merupakan kondisi yang mengancam nyawa, oleh karena itu pasien SKA beresiko mengalami mortalitas dan membutuhkan prediksi awal berupa marker jantung salah satunya adalah CK-MB. Pemeriksaan CK-MB dengan hasil yang meningkat dapat sebagai alat diagnostik infark miokard dan menunjukkan adanya nekrosis miosit. Diharapkan dengan mengetahui kadar CKMB yang meningkat dapat lebih berhati-hati dalam pencegahan terjadinya mortalitas pada pasien SKA. Studi retrospektif dengan desain penelitian casecontrol di RSI Jemursari Surabaya pada 60 pasien sindroma koroner akut pada Januari 2013 sampai Agustus 2017. Data dianalisis dengan analisis bivariat menggunakan uji $x^{2}$ atau chi-square. Hasil penelitian ini didapatkan nilai $\mathrm{p}<0,05$ yaitu 0,026 yang menunjukkan bahwa terdapat hubungan yang signifikan antara peningkatan nilai kadar CK-MB dengan peningkatan mortalitas pada pasien SKA. Hasil Odds ratio (OR) peningkatan CK-MB dengan kejadian mortalitas pada pasien SKA adalah OR 4,375 (IK 95\% 1,320-14,504), dimana dapat diartikan bahwa pada pasien SKA dengan hasil CK-MB meningkat mempunyai risiko 4,3 kali lebih besar untuk terjadinya mortalitas dibandingkan dengan pasien SKA dengan nilai CK-MB yang normal. Terdapat korelasi yang signifikan antara peningkatan kadar CK-MB dengan kejadian mortalitas pada pasien sindrom koroner akut.
\end{abstract}

Kata Kunci: $C K-M B$, mortalitas, sindroma koroner akut

\begin{abstract}
Acute Coronary Syndrome (ACS) is a condition that is life threatening, therefore $S K A$ patients are at risk of mortality and require initial predictions in the form of markers heart, one of which is CK-MB. CK-MB examination with increased results can be a diagnostic tool for myocardial infarction and shows the presence of myocyte necrosis. It is expected that knowing the increased levels of $C K-M B$ can be more careful in preventing mortality in SKA patients. Method: A retrospective study with research design case-control at Jemursari Hospital in Surabaya in 60 patients acute coronary syndrome from January 2013 to August 2017. Data were analyzed by bivariate analysis using $x^{2}$ or chi-square. Results: The results of this study obtained a value of $p<0.05$, which is 0.026 that there is a significant relationship between the increase in $C K-M B$ levels and increased
\end{abstract}


mortality in SKA patients. The results of the Odds ratio (OR) of CK-MB increase with the mortality incidence in SKA patients was OR $4.375(95 \%$ CI 1.32014.504), which can be interpreted that SKA patients with increased CK-MB had 4.3 times greater risk mortality compared with SKA patients with normal $C K-M B$ values. Conclusion: There is a significant correlation between the increase in $C K$ $M B$ levels with the incidence of mortality in patients with acute coronary syndrome

Keywords: $C K-M B$, mortality, acute coronary syndrome

\section{PENDAHULUAN}

\begin{tabular}{lrr} 
Penyakit & \multicolumn{2}{c}{ kardiovaskular } \\
menyebabkan & \multicolumn{2}{c}{ kematian dan } \\
kecacatan di & dunia. & Diperkirakan \\
setiap tahun & 17,3 juta orang
\end{tabular}
meninggal diakibatkan oleh penyakit kardiovaskular. Penyakit Jantung Koroner menduduki peringkat pertama yang menyumbang angka kematian pada tahun 2012 di Indonesia (Wong, 2014). Dari semua penyakit kardiovaskular, penyakit jantung koroner (PJK) merupakan manifestasi dominan dan diperkirakan oleh WHO sebagai penyebab utama kematian di dunia (Tumade, 2016). Penyakit Jantung Koroner dapat mengancam nyawa pada pasien yang dapat terjadi setiap saat, kondisi ini biasa disebut sindroma koroner akut (SKA). SKA terdiri dari STEMI (infark miokard dengan elevasi segmen ST), NSTEMI (infark miokard dengan non elevasi segmen ST) dan Unstable Angina (angina pektoris tidak stabil) (Tumade, 2016).

Menurut Departemen Kesehatan pada tahun 2013, di Indonesia terdapat sebanyak 478.000 pasien penyakit jantung koroner. Prevalensi infark miokard dengan segmen ST elevasi saat ini $40 \%$, meningkat dari sebelumnya yaitu $25 \%$ (Supriyantoro, dkk., 2013). Prevalensi penyakit jantung coroner berdasarkan gejala sebesar 2.650 .340 orang atau sekitar 1,5 persen, berdasarkan diagnosis dokter infark miokard sebesar 883.447 orang atau sekitar 0,5 persen, dan di provinsi Jawa Timur, prevalensi PJK berdasarkan diagnosis dokter dan gejala masing-masing adalah $0,5 \%$ dan 1,3\% (Mihardja, 2013).

Pemeriksaan marker nekrosis jantung seperti troponin $\mathrm{I} / \mathrm{T}$ atau creatine kinase-MB (CK-MB) digunakan sebagai alat diagnostik untuk infark miokard. Peningkatan kadar CK-MB telah dikaitkan dengan tingginya tingkat mortalitas pada pasien infark miokard akut (IMA) (Carvalho, 2016). Pada pasien yang menjalani intervensi koroner perkutan (PCI), peningkatan kadar CK-MB terus dikaitkan dengan peningkatan mortalitas pada tiga bulan, enam bulan, dan satu tahun kontrol (Lindsey, 2011; Bagai, 2014). Pada penelitian yang dilakukan oleh Carvalho dan Rassi pada tahun 2016, menunjukkan bahwa peningkatan kadar CK-MB yang bermakna dikaitkan dengan lama tinggal di rumah sakit dengan hasil gabungan yang buruk dari reinfarction, reintervention, dan kematian. Menurut Santos, et al., pada tahun 2011, bahwa kadar CKMB yang meningkat timbul sebagai variabel prognostik independen untuk titik akhir gabungan dari 
kematian atau infark berulang (reinfarction) dalam waktu 30 hari. Selain itu, sebuah analisis regresi logistik multipel memperlihatkan bahwa, ketika terjadi peningkatan CK-MB saja (tanpa pencantuman cTnT) maka peningkatan CK-MB menjadi tanda independen $(\mathrm{p}=0.002)$ untuk major cardiovascular events saat 6 bulan kontrol (Santos, et al., 2011; Carvalho, et al., 2016). Berdasarkan hal tersebut, peneliti ingin mengetahui hubungan nilai kadar CK-MB terhadap tingkat mortalitas pasien sindroma koroner akut (SKA) di RSI Jemursari Surabaya.

\section{METODE PENELITIAN}

Sebuah studi case-control dilakukan pada pasien pasien sindroma koroner akut yang dirawat di ICU dan rawat inap RSI Jemursari Surabaya periode Januari 2013 sampai Agustus 2017 dengan jumlah sampel 28 subjek. Teknik sampling yang digunakan adalah purposive sampling. Variabel independen (bebas) dalam penelitian ini adalah nilai kadar CK-MB yang berskala nominal dikotom (meningkat dan tidak meningkat) dan variabel dependen (terikat) pada penelitian ini adalah kejadian mortalitas yang juga berskala nominal dikotom (meninggal dan tidak meningkat/survived). Sumber data yang digunakan dalam penelitian ini adalah data sekunder yang diperoleh dari bagian rekam medik di RSI Jemursari Surabaya. Analisis data pada penelitian ini menghitung odds ratio (OR) untuk mengetahui peluang terjadinya kematian pada hasil nilai kadar CK-MB. Kemudian, untuk uji hipotesis digunakan uji khai-kuadrat (chi-square) untuk mengetahui hubungan antar-variabel, yaitu hubungan antara nilai kadar CK-MB dengan kejadian mortalitas

\section{HASIL}

Hasil uji statistik menunjukkan bahwa terdapat hubungan yang signifikan antara peningkatan nilai kadar CK-MB dengan kejadian mortalitas pada pasien SKA menggunakan uji Chi-square dengan hasil nilai $\mathrm{p}$-value adalah 0,026 dengan nilai $\mathrm{p}$-value $<0,05$ yang berarti bahwa $\mathrm{H}_{1}$ diterima. Selain itu, didapatkan nilai odds ratio pada penelitian ini adalah 4,375 (IK 95\% $1,320-14,504$ ) yang dapat diartikan bahwa odds ratio seorang pasien dengan nilai kadar CK-MB yang meningkat 4,4 kali lebih besar untuk terjadinya kematian dibandingkan pada pasien dengan nilai kadar CKMB yang normal. Selanjutnya, pada hasil perhitungan uji nominal dengan Phi dan Cramer's V untuk mengukur seberapa besar hubungan kekuatan antara nilai kadar CK-MB dengan mortalitas pada pasien SKA yaitu didapatkan nilai keduanya adalah sebesar 0,322 yang diamana nilai tersebut mendekati angka 0,5 maka kekuatan hubungan variabel nilai kadar CK-MB dengan variabel kejadian mortalitas pada pasien SKA adalah cukup kuat. 
Tabel 1. Distribusi Sampel Penelitian Berdasarkan Jenis Kelamin

\begin{tabular}{l|c|c|c}
\hline \multirow{2}{*}{ Jenis Kelamin } & \multicolumn{2}{|c}{ Meninggal } & Total \\
\hline Laki-laki & $22(36,7 \%)$ & $17(28,3 \%)$ & $39(65,0 \%)$ \\
\hline Perempuan & $8(13,3 \%)$ & $13(21,7 \%)$ & $21(35,0 \%)$ \\
\hline Total & $30(50 \%)$ & $30(50 \%)$ & $60(100 \%)$ \\
\hline
\end{tabular}

Tabel 2. Distribusi Sampel Penelitian Berdasarkan Usia

\begin{tabular}{c|c|c|c}
\hline \multirow{2}{*}{ Usia (tahun) } & \multicolumn{2}{|c|}{ Meninggal } & Tidak \\
\hline & $1(1,7 \%)$ & $1(1,7 \%)$ & $2(3,3 \%)$ \\
\hline 40 & $1(1,7 \%)$ & $6(10 \%)$ & $7(11,7 \%)$ \\
\hline $50-59$ & $14(23,3 \%)$ & $8(13,3 \%)$ & $22(36,7 \%)$ \\
\hline $60-69$ & $7(11,7 \%)$ & $10(16,7 \%)$ & $17(28,3 \%)$ \\
\hline $70-79$ & $6(10 \%)$ & $5(8,3 \%)$ & $11(18,3 \%)$ \\
\hline$>80$ & $1(1,7 \%)$ & $0(0,0 \%)$ & $1(1,7 \%)$ \\
\hline Total & $30(50 \%)$ & $30(50 \%)$ & $60(100 \%)$ \\
\hline Mean : $59,85 \pm 10,563$ & & & \\
\hline
\end{tabular}

Tabel 3. Distribusi Sampel Penelitian Berdasarkan Diagnosis SKA

\begin{tabular}{|c|c|c|c|}
\hline \multirow{2}{*}{ Diagnosis } & \multicolumn{2}{|c|}{ Meninggal } & \multirow{2}{*}{ Total } \\
\hline & Ya & Tidak & \\
\hline UA & $5(8,3 \%)$ & $14 \quad(23,3 \%)$ & $19(31,7 \%)$ \\
\hline NSTEMI & $11(18,3 \%)$ & $3 \quad(5 \%)$ & $14(23,3 \%)$ \\
\hline STEMI & $14(23,3 \%)$ & $13 \quad(21,7 \%)$ & $27(45 \%)$ \\
\hline Total & $30(50 \%)$ & $30 \quad(50 \%)$ & $60(100 \%)$ \\
\hline
\end{tabular}


Tabel 4. Distribusi Sampel Penelitian Berdasarkan Mortalitas

\begin{tabular}{c|c|c|c}
\hline \multirow{2}{*}{ Komplikasi } & \multicolumn{2}{|c|}{ Meninggal } & Total \\
\hline & Ya & Tidak & \\
\hline Ya & $26(43,3 \%)$ & $12(20 \%)$ & $38(63,3 \%)$ \\
\hline Tidak & $4(6,7 \%)$ & $18(30 \%)$ & $22(36,7 \%)$ \\
\hline Total & $30(50 \%)$ & $30(50 \%)$ & $60(100 \%)$ \\
\hline
\end{tabular}

Tabel 5. Distribusi Sampel Penelitian Berdasarkan Jenis Komplikasi

\begin{tabular}{c|c|c|c}
\hline \multirow{2}{*}{ Jenis Komplikasi } & \multicolumn{2}{|c}{ Meninggal } & \multirow{2}{*}{ Total } \\
\hline & Ya & Tidak & \\
\hline Syok Kardiogenik & $14(36,8 \%)$ & $1(2,6 \%)$ & $15(39,5 \%)$ \\
\hline Gagal Jantung & $9(23,7 \%)$ & $11(28,9 \%)$ & $20(52,6 \%)$ \\
\hline Aritmia & $3(7,9 \%)$ & $0(0 \%)$ & $3(7,9 \%)$ \\
\hline Total & $26(68,4 \%)$ & $12(31,6 \%)$ & $38(100 \%)$ \\
\hline
\end{tabular}

Tabel 6. Distribusi Sampel Penelitian Berdasarkan Hasil CK-MB

\begin{tabular}{|c|c|c|c|c|}
\hline \multirow{2}{*}{ Nilai CK-MB } & \multicolumn{3}{|c|}{ Meninggal } & \multirow{2}{*}{ Total } \\
\hline & Ya & & Tidak & \\
\hline Meningkat & $25(41,7 \%)$ & 16 & $(26,7 \%)$ & $41(68,3 \%)$ \\
\hline Normal & $5(8,3 \%)$ & 14 & $(23,3 \%)$ & $19(31,7 \%)$ \\
\hline Total & $30(50 \%)$ & & $30(50 \%)$ & $60(100 \%)$ \\
\hline
\end{tabular}

Tabel 7. Hubungan Nilai Kadar CK-MB dengan Mortalitas

\begin{tabular}{|c|c|c|c|c|c|}
\hline \multirow{2}{*}{ Nilai CK-MB } & \multicolumn{2}{|c|}{ Meninggal } & \multirow{2}{*}{ Nilai p } & \multirow{2}{*}{ OR (IK 95\%) } & \multirow{2}{*}{$\begin{array}{l}\text { Nilai Phi dan } \\
\text { Cramer's V }\end{array}$} \\
\hline & Ya & Tidak & & & \\
\hline Meningkat & $25(41,7 \%)$ & $16(26,7 \%)$ & & 4,375 & \\
\hline Normal & $5(8,3 \%)$ & $14(23,3 \%)$ & 0,026 & $\begin{array}{l}(1,320- \\
14,504)\end{array}$ & 0,322 \\
\hline
\end{tabular}




\section{PEMBAHASAN}

Hasil penelitian didapatkan pasien sindroma koroner akut berdasarkan jenis kelamin, didapatkan laki-laki adalah sebanyak 39 orang $(65 \%)$, sedangkan perempuan adalah 21 orang (35\%). Hasil ini didukung dengan penelitian Ramadhani (2013), yang menunjukkan bahwa penderita SKA perempuan lebih sedikit dibandingkan perempuan pada tahun 2010 di RSUP Prof. Dr. R. D. Kondou Manado. Sindroma Koroner akut (SKA) lebih rentan terjadi pada laki-laki dibanding perempuan. Hal ini dikarenakan perempuan memiliki hormon estrogen yang merupakan protektan terhadap kejadian aterosklerosis (Antman \& Braundwald, 2010; Ismantri, 2009).

Hasil penelitian didapatkan 2 orang pasien termasuk kelompok usia <40 tahun didapatkan sebanyak 2 orang $(3,3 \%)$ yang masing-masing 1 orang $(1,7 \%)$ meninggal dengan usia 31 tahun dan tidak meninggal dengan usia 38 tahun, 7 orang pasien $(11,7 \%)$ termasuk dalam kelompok usia 40-49 tahun, 22 orang pasien $(36,7 \%)$ termasuk dalam kelompok usia 50-59 tahun, 17 orang pasien $(28,3)$ termasuk dalam kelompok usia 60-69 tahun, dan 11 orang pasien $(18,3 \%)$ termasuk dalam kelompok usia 70-79 tahun. Hal ini sesuai dengan hasil penelitian yang dilakukan oleh Ramadhani (2013) yang menunjukkan bahwa usia 41-60 tahun adalah usia yang paling banyak diderita oleh pasien SKA. Hal ini sesuai dengan teori yang menjelaskan bahwa usia $>45$ tahun untuk laki-laki dan usia >55 tahun untuk perempuan adalah faktor risiko terkena sindroma koroner akut (Ramadhani, 2013). Bertambahnya usia akan menyebabkan pembuluh darah mengalami perubahan progresif dan berlangsung secara terus menerus dalam jangka waktu yang lama. Hasil penelitian didapatkan hubungan antara umur dan kadar kolesterol yaitu kadar kolesterol total akan meningkat dengan bertambahnya usia. Usia 20 tahun merupakan perubahan yang paling dini pada pembuluh arteri koroner. Usia 40 tahun arteri lain mulai bermodifikasi dan meningkat dengan bertambahnya usia (Supriyono, 2008).

Hasil distribusi diagnosis didapatkan diagnosis terbanyak adalah STEMI sebanyak 27 orang (45\%), diikuti dengan UA sebanyak 19 orang $(31,7 \%)$, dan terakhir dengan diagnosis NSTEMI sebanyak 14 orang $(23,3 \%)$. Hasil penelitian Antoniades et al., (2014) menunjukkan bahwa STEMI merupakan prevalensi diagnosis SKA.

Hasil distribusi usia berdasarkan klasifikasi diagnosis didapatkan pada penelitian ini jumlah diagnosis NSTEMI dan STEMI terbanyak pada usia 50-59 tahun dan UA terbanyak pada kelompok usia. Hasil penelitian Antoniades et. al. (2014) menunjukkan hal yang sama dengan frekuensi kasus NSTEMI dan STEMI tertinggi pada umur 50-59 tahun dan kasus UA tertinggi pada umur 60-69 tahun (Antoniades, et al., 2014). Selanjutnya, hasil distribusi sampel penelitian berdasarkan faktor risiko didapatkan data bahwa pasien SKA memiliki faktor risiko dan sebagian besar pasien memiliki lebih dari satu faktor risiko termasuk usia dan jenis kelamin. Penelitian yang dilakukan Framingham tentang Multiple Risk 
Factors Intervention dan Prospective Cardiovascular Munster (PROCAM), diketahui bahwa faktor risiko seseorang untuk terkena SKA ditentukan melalui interaksi dua atau lebih faktor risiko (Wong, 2014; Lee, dkk., 2015).

Pasien SKA dalam penelitian ini didapatkan faktor risiko riwayat merokok pada 6 orang $(10 \%)$ dan 54 orang $(90 \%)$ tidak mempunyai riwayat merokok. Hasil ini sesuai dengan penelitian Rosmiatin tahun 2012 yang menunjukkan bahwa 9 orang penderita memiliki riwayat merokok sedangkan 69 orang tidak memiliki riwayat merokok (Rosmiatin, 2012). Hal ini sesuai dengan berbagai teori yang menyatakan bahwa merokok merupakan faktor risiko terjadinya sindroma koroner akut. Beban miokard yang diakibatkan rokok akan menurunkan konsumsi oksigen dalam tubuh sehingga dapat menyebabkan takikardi, permeabilitas dinding pembuluh darah akan berubah, terjadinya vasokonstriksi pembuluh darah, dan meningkatkan resiko sindroma koroner akut karena rokok akan merubah $5-10 \% \mathrm{Hb}$ menjadi karboksi-Hb (Grundy, et al., 1999; Burazerl, et al., 2007).

Berdasarkan analisis bivariat, didapatkan nilai $\mathrm{p}$ adalah 0,026 , yang dimana nilai $\mathrm{p}<0,05$ pada peningkatan nilai kadar CK-MB terhadap kejadian mortalitas. Hal ini menunjukkan bahwa peningkatan nilai kadar CK-MB dengan tingkat mortalitas pada pasien SKA memiliki hubungan yang signifikan. Pada hasil statistik dengan Phi dan Cramer's V menunjukkan hasil 0,322 yang bernilai positif, sehingga semakin meningkat nilai kadar CK$\mathrm{MB}$, maka risiko terjadinya mortalitas akan semakin meningkat pula. Selain itu, seorang pasien yang mengalami SKA dengan peningkatan nilai kadar CK-MB memiliki risiko untuk terjadinya kematian yaitu sebesar 4,375 kali (OR 4,375 [IK $95 \% ; 1,320$ - 14,504]) lebih besar daripada pasien SKA dengan nilai kadar CK-MB yang normal.

Hasil penelitian ini didukung dengan penelitian Yee $\mathrm{KC}$ et al., pada tahun 2003 yang melakukan penelitian pada 542 pasien SKA, didapatkan bahwa terdapat morbiditas dan mortalitas yang tinggi pada pasien dengan peningkatan nilai kadar CK-MB dibandingkan dengan pasien tanpa peningkatan nilai kadar CK-MB. Penelitian tersebut juga menyimpulkan bahwa, pada pasien dengan nilai troponin yang negatif, nilai kadar CK-MB secara signifikan dapat mengidentifikasi pasien dengan risiko tinggi untuk terjadinya kematian dan major cardiac events pada enam bulan follow-up (Yee, et al., 2003).

Penelitian yang dilakukan Santos, et al., pada tahun 2011, yang melakukan follow-up selama 30 hari pada pasien NSTEMI di rumah sakit dan menghasilkan terdapat $2 \%$ mortalitas di rumah sakit dan $2.23 \%$ mengalami infark berulang (reinfarction) di rumah sakit dalam 30 hari, jumlah pasien dengan kejadian kombinasi kematian atau infark berulang (reinfarction) adalah $5,3 \%$. Pada analisis regresi multiple, memperlihatkan bahwa ketika hanya CK-MB yang dimasukkan ke dalam model (tanpa memasukkan cTnT), CK-MB muncul sebagai penanda independen $(\mathrm{p}=0,002)$ untuk terjadinya major cardiovascular events pada 6 bulan follow-up (Santos, et, al., 2011). 
Peningkatan dalam enzim spesifik jantung CK-MB sebagai ciri khas infark miokard akut, dan peningkatan kadar sering ditafsirkan sebagai kerusakan dari sel miokardium. Peningkatan biomarker jantung dalam pembuluh darah mencerminkan cidera yang nantinya akan menyebabkan nekrosis sel miokardium. Kemungkinan keadaan yang dapat mengeluarkan protein struktural dari miokardium, antara lain onset normal sel miokardium, apoptosis, peningkatan permeabilitas dinding sel, dan nekrosis miosit (Carvalho, et, al., 2016).

Pelepasan sitokin inflamatorik setelah infark miokardium dapat menyebabkan ekpresi nitrogen monoksida yang dapat diinduksi, kelebihan nitrogen monoksida, dan vasodilatasi yang tidak sesuai. Selanjutnya, hal tersebut menurunkan perfusi sistemik dan koroner lebih jauh. Depresi kontraktilitas miokardium, biasanya akibat iskemia, menyebabkan penurunan curah jantung dan tekanan darah (TD), sehingga miokardium mengalami hipoperfusi dan selanjutnya memperparah iskemia serta depresi curah jantung. Disfungsi sistolik miokardium menurunkan volume sekuncup dan, bersama-sama dengan disfungsi diastolik, menyebabkan peningkatan tekanan diastolik akhir ventrikel kiri PCWP serta kongesti paru. Penurunan perfusi koroner memperburuk iskemia dan disfungsi miokardium progresif sehingga menurunkan kerja jantung secara drastis, yang jika tidak tertangani, sering berakibat fatal (Loscalzo, 2015).

Selama fase akut dari infark miokard, kematian mendadak biasanya merupakan hasil dari iskemia yang menyebabkan aritmia karena kematian ventrikel. Komplikasi mekanis menghasilkan gangguan hemodinamik yang sangat besar, seperti ruptur ventrikel atau otot papilaris, tamponade pericardium, dan disfungsi katup iskemik juga dapat menghasilkan seperti kematian mendadak karena aritmia, bahkan meskipun jika pada ritme tidak terjadi fibrilasi ventrikel. Urutan peristiwa yang sama dapat terjadi pada pasien dengan syok kardiogenik sebagai akibat dari nekrosis miokard yang luas (Bunch, 2007).

\section{SIMPULAN}

Pasien SKA dengan peningkatan nilai kadar CK-MB mempunyai risiko 4,375 kali lebih besar untuk terjadinya mortalitas dibanding pasien dengan nilai kadar CK-MB yang normal. Peningkatan dalam enzim spesifik jantung CKMB sebagai ciri khas infark miokard akut, dan peningkatan kadar sering ditafsirkan sebagai kerusakan dari sel miokardium.

\section{DAFTAR PUSTAKA}

Antman, E.M. \& Braundwald, E. (2010). Harrison's Principles of Internal Medicine (17th ed). New South Wales: McGraw Hill.

Antoniades L, Christodoulides T, Georgiou P, Hadjilouca C, Christodoulou E, Papasavas E, et al. (2014) Epidemiology of acute coronary syndromes in the Mediterranean Island of Cyprus (CYPACS study, Cyprus study of acute coronary syndromes). Hellenic J Cardiol; 55:139-49. 
Ariandiny M, Afriwardi, Syafri M. (2014). Gambaran tekanan darah pada pasien sindroma koroner akut di RS Khusus Jantung Sumatera Barat tahun 2011-2012. Jurnal Kesehatan Andalas; 3:191-5.

Bunch, TJ, Hohnloser SH, Gersh BJ. (2007). Mechanisms of Sudden Cardiac Death in Myocardial Infarction Survivors. Circulation, 115:2451-2457.

Burazerl G, Goda A, Sulo G, Stefa J, Roshi E, Kark J. (2007). Conventional risk factors and acute coronary syndrome during a period of sosioeconomic transition: population-based case-control study in Tirana, Albania. Croat Med J; 48:225-33.

Carvalho G., Rassi S. (2016). The prognostic value of CK-MB in Acute Myocardial Infarction in developing countries: a descriptive study. Angiology, 4:3.

Chin CT, Wang TY, Li S, Wiviott $\mathrm{SD}$, deLemos JA, Kontos MC, et al. (2012). Comparison of the prognostic value of peak creatine kinase-MB and troponin levels among patients with acute myocardial infarction: A report from the acute coronary treatment and intervention outcomes network registry-get with the guidelines. Clinical Cardiology; 35(7):424-429.

Goodarce, Steve, et al. 2005. Which diagnostic tests are most useful in a chest pain unit protocol?. BMC Emergency Medicine; 5:6.

Grundy SM, Pasternak R, Greenland P, Smith S, Fuster V. 1999. Assessment of cardiovascular risk by use of multiple-riskfactor assessment equations. Circulation; 100: 1481-92.

Ismantri F. (2009). Prevalensi penderita penyakit jantung koroner yang menjalani intervensi koroner perkutan di Rumah Sakit Binawaluya tahun 2008- 2009 (skripsi). Universitas Islam Negeri Syarif Hidayatullah.

Lee JA, Rotty L, Wantania FE. (2015). Profil lipid pada pasien dengan penyakit jantung koroner di BLU RSUP Prof. Kandou tahun 2012. eCl; 3:485-9.

Li Yulong, Rukshin Iris, et al. (2014). The Impact of the 2008-2009 Economic Recession on Acute Myocardial Infarction Occurrences in Various Socioeconomic Areas of Raritan Bay Region, New Jersey. Journal of Medical Sciences. 6(5) : 215-18.

Lindsey JB, Kennedy KF, Stolker JM, Gilchrist IC, Mukherjee D, et al. (2011). Prognostic implications of creatine kinaseMB elevation after percutaneous coronary intervention: Results from the Evaluation of Drug-Eluting Stents and Ischemic Events (EVENT) registry. Circ Cardiovas Interv 5: 474-480.

Loscalzo, J. (2015). Harrison Kardiologi dan Pembuluh Darah Ed. 2. Jakarta:EGC.

Mihardja LK, Delima, Soetiarto F, Suhardi, Kristanto AY. (2013). Penyakit tidak menular. In: Kementerian Kesehatan Republik Indonesia, penyunting. Riset Kesehatan 
Dasar. Jakarta: Badan Penelitian dan Pengembangan Kesehatan Kementeri-an Republik Indonesia, p. 83-99.

Ramadhani BYS, Rotty LWA, Wantania F. (2013). Gambaran hematologi pada pasein sindroma koroner akut yang dirawat di BLU RSUP Prof. Dr. R. D. Kandou Manado tahun 2010. Journal eBiomedik; 1:12-6.

Santos ES, Valeria TB, Marcos PP, Luiz M, Ari T, Alvaro A. (2011). Comparison between cardiac troponin I and CK-MB mass in acute coronary syndrome without ST elevation. Arq Bras Cardiol; 96 (3): 179-187.

Supriyantoro, Oscar P, Vensya S, dkk. (2013). Depkes Litbang. Riset Kesehatan Dasar. Kementrian Kesehatan Republik Indonesia. Jakarta.

Supriyono, M. (2008). Faktor-faktor yang Berpengaryh Terhadap Kejadian Penyakit Jantung Koroner Pada Kelompok Usia $\leq 45$ Tahun. Tesis. Semarang: Universitas Diponegoro.
Torry, S. R. V, Panda, A. L. and Ongkowijaya, J. (2013) 'Gambaran Faktor Risiko Penderita Sindroma Koroner Akut', Universitas Sam Ratulangi, pp. 1-8.

Tumade B., Jim EL., Joseph VFF. (2016). Prevalensi sindroma koroner akut di RSUP Prof. Dr. R. D. Kandou Manado periode 1 Januari 2014 - 31 Desember 2014. Jurnal e-Clinic, Vol. 4, No. 1.

Wong WD. (2014). Epidemiological studies of CHD and the evolution of preventive cardiology. Nature. 11:276-89.

Xuming D, Jan BW, Karen PA. (2016). Acute coronary syndrome in the older adults. Journal of Gaeriatric Cardiology; 13:101-108.

Yee KC, Mukherjee D, Smith DE, Kline-Rogers EM, Fang J, Mehta RH, et al. (2003). Prognostic significance of an elevated creatine kinase in the absence of an elevated troponin I during an acute coronary syndrome. Am $J$ Cardiol; 92(12):1442-4. 